\title{
Supporting Sustainable Manufacturing Practices Implementation using Design Structure Matrix in the Algerian Economy
}

\author{
Nassim Keddari ${ }^{1}$, Sonia Kherbachi ${ }^{2,3}$, Naima Benkhider ${ }^{2}$ \\ ${ }^{1}$ LED, FSECSG, University of Bejaia, 06000, Bejaia, Algeria \\ ${ }^{2}$ LRMTQ, FSECSG, University of Bejaia, 06000, Bejaia, Algeria \\ ${ }^{3}$ University of Science and Technology Beijing, Beijing 100083, China
}

\begin{abstract}
Sustainable manufacturing practices are becoming the main goal of developing economies. This study identifies effective industrial, trade, and innovation policies that support strategies toward sustainable manufacturing practices implementation. This study provides a framework to achieve the research aim in the Algerian economy, where sustainability issues are especially relevant. Initially, the common sustainable manufacturing practices are collected from literature resources end expert views. The random walk method is adopted using the Policies Design Structure Matrix, expressed as the dependency between two given policies. Results show that innovation policies encourage sustainable manufacturing practices implementation more than trade and industrial policies. For firms in such developing and emerging economies, managerial insights are relevant for implementing the proposed random walk process to relieve their weaknesses toward sustainable manufacturing practices.
\end{abstract}

Keywords: Sustainable manufacturing practices, sustainable strategies, developing economies, random walk, Design Structure Matrix

\section{Introduction}

With its main goal of reduced or zero damaging impacts on society, environment, and economy, sustainable manufacturing has become a widely held research topic. However, relevant concepts have evolved with: environmentally conscious manufacturing (Ilgin \& Gupta, 2010), green manufacturing (Deif, 2011), lean manufacturing (Melton, 2005), and so forth. For effective implementation of sustainable manufacturing practices (SMP), strategies (Deif, 2011), policies (Wang, Subramanian, Gunasekaran, Abdulrahman, \& Liu, 2015), and indicators (Madan Shankar, Kannan, \& Udhaya Kumar, 2017) are investigated. In that wise, it is required to understand the practices that are needed for the implementation of sustainable manufacturing. Hence, this study aspires to examine sustainable manufacturing practices in the Algerian economy. As a developing economy, Algeria is considered an ideal case to identify effective sustainable manufacturing practices and validate the proposed model. According to (Abdul-Rashid, Sakundarini, Raja Ghazill, \& Thurasamy, 2017), manufacturing in developing sectors plays a significant role in the economy. Most manufacturing strategies endure limited to either one or two dimensions. 
Supporting Sustainable Manufacturing Practices Implementation using Design Structure Matrix in the Algerian Economy

No robust guidelines exist yet to ensure sustainable manufacturing implementation success; available literature defeats to consider such a complex research topic from the triple bottom line perspective (social, environmental, and economic). In addition, no studies are exploring the status of sustainability issues in the Algerian economy, which justifies the study's geographical focus. For these purposes, the resulting research questions were tackled.

$\checkmark$ What are the common sustainable manufacturing practices that contribute to a successful implementation?

$\checkmark$ What are the strategies implicated in the application of sustainable manufacturing practices?

$\checkmark$ What is the most policy that influences the successful implementation of sustainable manufacturing in the Algerian economy?

In this research paper, we address the design structure matrix (DSM) method to explore policies promoting sustainable strategies enabling SMP application. We discuss the appropriate literature review regarding sustainable manufacturing practices. The manufacturing sector from Algeria is used to approve our concepts and method.

\section{Literature review}

Firms are running hard to attain sustainable development goals due to rising pressures from their stakeholders and are dynamic in rethinking their strategies to preserve sustainability in their operations and services. Hence, sustainable manufacturing practices concerns have become a significant challenge for public and private firms over many industries and sectors (Wang, Subramanian, Gunasekaran, Abdulrahman, \& Liu, 2015). Firms' undertaking towards SMP is seen among developed economies. More recently, it is considered a key strategy in emerging economies because many firms are located in transitional economies (Madan Shankar, Kannan, \& Udhaya Kumar, 2017).

The majority of studies explored sustainable manufacturing practices in which three key dimensions of practices were studied: energy saving, supply chain restructuring, and sustainable material and design (Wang, Subramanian, Gunasekaran, Abdulrahman, \& Liu, 2015; Madan Shankar, Kannan, \& Udhaya Kumar, 2017). These practices' implementation is supported by numerous sustainable strategies and policies, as shown in Tables 1 and 2 (Nordin, Ashari, \& Rajemi, 2014). In their study, Rosen \& Kishawy reconsidered SMP with a generalized perspective, and they found that the key contributors of sustainable manufacturing are the use of different sustainable indicators (Rosen \& Kishawy, 2012). Joung et al., also considered the indicators of sustainable manufacturing to ensure sustainable performance (Joung, Carrell, Sarkar, \& Feng, 2013). They classify these indicators into several dimensions, including environmental stewardship, economic growth, and social well-being, as shown in Table 1. 
Table 1. Collected common sustainable manufacturing practices.

\begin{tabular}{|c|c|c|c|c|c|c|}
\hline DIMENSIONS & $\mathbf{N}^{\circ}$ & & $\mathbf{N}^{\circ}$ & Strategies & Indicators & \\
\hline & & Practices & & & \multirow{4}{*}{$\begin{array}{l}\text {-Reducing non- } \\
\text { value-added } \\
\text { activities in long } \\
\text { term business } \\
\text { activities } \\
\text {-Tracking } \\
\text { company's } \\
\text { environmental } \\
\text { management } \\
\text { system } \\
\text {-Greenhouse gas } \\
\text { measurement } \\
\text {-Technological } \\
\text { advancement }\end{array}$} & \multirow{4}{*}{$\begin{array}{c}\text { Authors } \\
\text { (Afum, et al., } \\
\text { 2020); } \\
\text { (Abdul- } \\
\text { Rashid, } \\
\text { Sakundarini, } \\
\text { Raja Ghazill, } \\
\text { \& } \\
\text { Thurasamy, } \\
\text { 2017); } \\
\text { (Digalwar, } \\
\text { Thomas, \& } \\
\text { Rastogi, } \\
\text { 2021); }\end{array}$} \\
\hline \multirow[b]{3}{*}{ Economic } & SMP1 & $\begin{array}{l}\text { Reduction of } \\
\text { manufacturin } \\
\text { g cost }\end{array}$ & $\mathrm{S} 1$ & $\begin{array}{l}\text { Reducing } \\
\text { operational } \\
\text { cost }\end{array}$ & & \\
\hline & SMP2 & $\begin{array}{l}\text { Improved } \\
\text { process } \\
\text { performance }\end{array}$ & $\mathrm{S} 2$ & $\begin{array}{l}\text { Sustainable } \\
\text { material \& } \\
\text { design }\end{array}$ & & \\
\hline & SMP3 & $\begin{array}{l}\text { Supply chain } \\
\text { restructuring }\end{array}$ & S3 & $\begin{array}{l}\text { Supplier } \\
\text { support }\end{array}$ & & \\
\hline \multirow{3}{*}{ Environmental } & SMP4 & $\begin{array}{l}\text { Energy } \\
\text { saving }\end{array}$ & S4 & $\begin{array}{l}\text { Business } \\
\text { waste }\end{array}$ & \multirow{3}{*}{$\begin{array}{l}\text {-Saving } \\
\text { materials and } \\
\text { energy in } \\
\text { short-term } \\
\text { business } \\
\text { operations. } \\
\text {-Ordering, } \\
\text { capital, } \\
\text { warehousing, } \\
\text { and } \\
\text { replenishment } \\
\text { costs. } \\
\text {-Prevent, } \\
\text { remove or } \\
\text { repair the } \\
\text { damage } \\
\text { caused by } \\
\text { business } \\
\text { activities. }\end{array}$} & \multirow{3}{*}{$\begin{array}{l}\text { (Deif, 2011); } \\
\text { (Fadzlin, } \\
\text { Zubir, \& } \\
\text { Habidin, } \\
\text { 2012); } \\
\text { (Singh, } \\
\text { Olugu, Musa, } \\
\text { \& Mahat, } \\
\text { 2016); (Ilgin } \\
\text { \& Gupta, } \\
\text { 2010); }\end{array}$} \\
\hline & SMP5 & $\begin{array}{l}\text { Promoting 6R } \\
\text { (reduce, } \\
\text { reuse, } \\
\text { recycle, } \\
\text { recover, } \\
\text { redesign, } \\
\text { remanufactur } \\
\text { e) concepts }\end{array}$ & S5 & $\begin{array}{l}\text { Green image: } \\
\text { Firms' } \\
\text { reputation in } \\
\text { respect of the } \\
\text { environment } \\
\text { in the long } \\
\text { term. }\end{array}$ & & \\
\hline & SMP6 & $\begin{array}{l}\text { Using } \\
\text { advanced } \\
\text { material and } \\
\text { manufacturin } \\
\text { g techniques }\end{array}$ & S6 & $\begin{array}{l}\text { Improve } \\
\text { environment } \\
\text { policy } \\
\text { effectiveness }\end{array}$ & & \\
\hline \multirow{3}{*}{ Social } & SMP7 & $\begin{array}{l}\text { Employee } \\
\text { education and } \\
\text { training }\end{array}$ & S7 & $\begin{array}{l}\text { Technology } \\
\text { improvement } \\
\text { to contribute } \\
\text { to the } \\
\text { development } \\
\text { of } \\
\text { communities. }\end{array}$ & \multirow{3}{*}{$\begin{array}{l}\text {-Profit created } \\
\text { per worker. } \\
\text {-Employee } \\
\text { discontent and } \\
\text { turnover rate } \\
\text { reduction } \\
\text {-Product life } \\
\text { cycle } \\
\text { assessment. } \\
\text {-Employee } \\
\text { motivation } \\
\text {-Fair public } \\
\text { image and } \\
\text { employee } \\
\text { morale } \\
\text { establishment }\end{array}$} & \multirow{3}{*}{$\begin{array}{c}\text { (Joung, } \\
\text { Carrell, } \\
\text { Sarkar, \& } \\
\text { Feng, 2013); } \\
\text { (Nordin, } \\
\text { Ashari, \& } \\
\text { Rajemi, } \\
\text { 2014); } \\
\text { (Wang, } \\
\text { Subramanian, } \\
\text { Gunasekaran, } \\
\text { Abdulrahman } \\
\text { \& Liu, } \\
\text { 2015); } \\
\text { (Rosen \& } \\
\text { Kishawy, } \\
\text { 2012) }\end{array}$} \\
\hline & SMP8 & $\begin{array}{l}\text { Producing } \\
\text { environmenta } \\
\text { lly friendly } \\
\text { and safe } \\
\text { products }\end{array}$ & S8 & $\begin{array}{l}\text { social well- } \\
\text { being: } \\
\text { employees' } \\
\text { health and } \\
\text { safety at work }\end{array}$ & & \\
\hline & SMP9 & $\begin{array}{l}\text { Personal } \\
\text { protective } \\
\text { equipment }\end{array}$ & S9 & $\begin{array}{l}\text { Firm culture } \\
\text { and } \\
\text { community } \\
\text { engagement }\end{array}$ & & \\
\hline
\end{tabular}

Sustainable policies imply developing strategies to encourage practices that address problems, such as climate change, supplier support, and sustainable material \& design (Millar \& Russell, 2011). The different policies cover more than environmentally-friendly activities; they also conduct manufactories toward achieving other sustainable goals, for instance, reducing operational cost and technology improvement contributing to the development of communities. 
Supporting Sustainable Manufacturing Practices Implementation using Design Structure Matrix in the Algerian Economy

Table 2. Collected common policies.

\begin{tabular}{ccc}
\hline Policies & $\mathbf{N}^{\circ}$ & Authors \\
\hline Industrial policies & POL1 & (Rodrik, 2014); (Millar \& Russell, 2011) \\
\hline Trade policies & POL2 & (Millar \& Russell, 2011); (Fiorini \& Hoekman, 2018) \\
\hline Innovation policies & POL3 & (Fagerberg, 2017); (Nill \& Kemp, 2009) \\
\hline
\end{tabular}

Zooming into the three dimensions of SMP, some studies found that sustainable operations management practices would raise operational, financial, and market performance (Fadzlin, Zubir, \& Habidin, 2012). This performance can be achieved by cost savings, superior quality and productivity, reputation and market share, and better new market opportunities. Also, it has been found a greater contribution of employee orientation on firm performance compared to other primary stakeholders' orientations such as customers, suppliers, shareholders, and communities (Melton, 2005).

In this study, the three layers are selected relied on the Unites Nations 2030 Agenda for Sustainable Development, entitled Agenda 2030. It is an agenda for people, for the planet, for prosperity, for peace, and through partnerships. As shown in Figure 1, the model is made of three sequential steps. Firstly, the designated strategies, policies, and SMP are presented in an object-user heterogeneous network, and interconnections between them (see Figure 1(a)). The first layer is made up of the adopted sustainable strategies, such as business waste, social well-being, etc.; the third layer comprises SMP implemented to achieve sustainable development goals. These strategies and practices should be governed by public policies, which are defined in the second layer (see Figure 1(b)). Secondly, in the random walk simulation step, we pretend that a random walker strolls in the constructed object-user network. As illustrated in Figure 1(b), the walker can shift from a node to another in the same layer, or it can jump from one layer to another. Specifically, this process is determined by a transition matrix for multiple users. Thirdly, upon finishing the simulation, we extract probabilities that the walker stays in candidate objects and prioritize these objects accordingly. The interactions between the three layers are presented by a set of indicators. These indicators characterize the different initiatives taken by states regarding SMP and strategies adoption, such as saving materials and energy, employee motivation, and technological advancement.

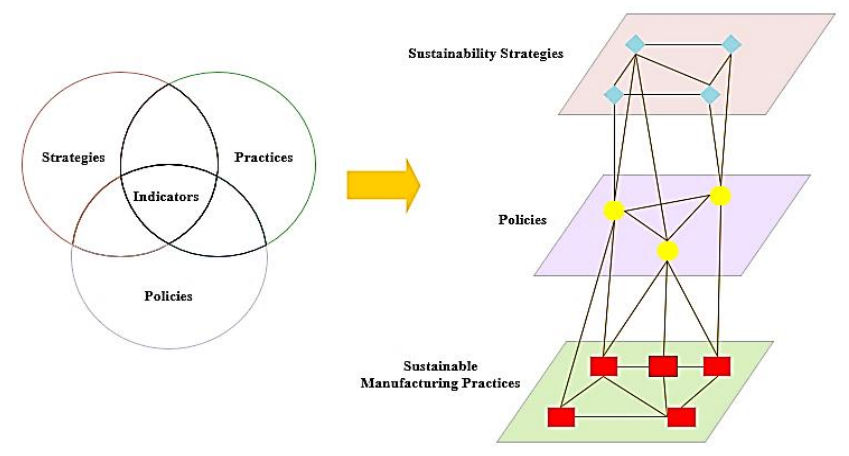

Figure 1. Research Framework 


\section{Methods and Material}

Design Structure Matrix (DSM) method supports complex systems management. It is designed by fixing complex system elements and how they relate to each other. The DSMbased method has been recognized as valuable in appreciating, conceiving, and optimizing complex system architectures such as products, organizations, and processes (Browning, 2001). The analytic hierarchy methodology (AHP), developed by T.L. Saaty (Saaty, 1984), enables assigning a value indicating the preference degree for a given alternative to each additional alternative (Leal, 2020). Such values can be applied to categorize and select alternatives based on a hierarchical structure. Contempt its wide applicability, the AHP methodology endures from notable limits: it requires a large number of comparisons to make a decision. Also, it does not consider iteration feedback between analyzed elements because comparisons are made only between one element and all other elements (Singh, Olugu, Musa, \& Mahat, 2016). Recent approaches have combined AHP with other methods such as Random walk. The concept of the random walk was first proposed by Karl Pearson in 1905 (Pearson, 1905). It can be defined as a stochastic process that illustrates a path that consists of a series of random steps on certain mathematical spaces such as integers (Masuda, A. Porter, \& Lambiotte, 2017). A basic example is a random walk on the integer number line, $\{Z\}$, which begins at 0 , and each step moves about $\{+1\}$ or $\{-1\}$ with identical probability (Pinsky \& Karlin, 2011). Another example includes Brownian motion, which presents the path drawn by a molecule as it moves in a liquid or a gas (Kac, 1947). The random walks theory is the succession of a concept called a Markov chain that had previously been developed in the statistical literature (Chung \& AitSahlia, 2003).

Building compromise about element weighting during the random walk process creates a shared understanding of firms' priorities and detailed information about addressing them. Then, the detailed information is organized into statements of arrangement. These statements are grouped and sequenced using DSM into an improvement plan. The DSM model can be divided into three blocks, corresponding to the three layers (S, POL and SMP ) and their interconnections. The Policies DSM is constructed based on the PoliciesSMP influence matrix (POL-SMP DMM) and the Policies- sustainable strategies influence matrix (POL-S DMM). This DSM allows defining the final policies rank to identify the best policies encouraging sustainable strategies permitting a successful SMP implementation in the Algerian economy. The first step in the Random Walk method is to calculate direct influence matrices. These matrices are calculated with the help of expert views and the relationships stated in the literature. A mutual relationship among the attributes is being evaluated using the binary system. The zero value is granted if there is no direct influence between the attributes. The one value is assigned to the variables having a direct influence. This scoring is used to rank the different strategies and practices adopted by states. The scoring variation is defined according to established national action plan priorities to recommend top rank policies encouraging sustainable manufacturing practices. Based on expert views and the relationships stated in the literature, a direct relationship matrix among sustainable strategies was set up, in table 3 , with variables denoted as "S". 
Supporting Sustainable Manufacturing Practices Implementation using Design Structure Matrix in the Algerian Economy

Table 3. Sustainable strategies direct influence matrix (Sustainable strategies DSM)

\begin{tabular}{llllllllll}
\hline & S1 & S2 & S3 & S4 & S5 & S6 & S7 & S8 & S9 \\
\hline S1 & 1 & 1 & 1 & 1 & 0 & 0 & 1 & 0 & 0 \\
S2 & 1 & 1 & 0 & 1 & 1 & 1 & 1 & 1 & 1 \\
S3 & 1 & 0 & 1 & 0 & 1 & 0 & 0 & 0 & 0 \\
S4 & 1 & 1 & 0 & 1 & 1 & 1 & 1 & 0 & 1 \\
S5 & 0 & 1 & 1 & 1 & 1 & 1 & 1 & 1 & 1 \\
S6 & 0 & 1 & 0 & 1 & 1 & 1 & 1 & 1 & 1 \\
S7 & 1 & 1 & 0 & 1 & 1 & 1 & 1 & 1 & 1 \\
S8 & 0 & 1 & 0 & 0 & 1 & 1 & 1 & 1 & 1 \\
\hline
\end{tabular}

The second direct influence matrix designed concerns different policies encouraging sustainable strategies, therefore supporting the implementation of sustainable manufacturing practices. These policies are symbolized in table 4 as "POL".

Table 4. Policies direct influence matrix (Policies DSM)

\begin{tabular}{cccc}
\hline & POL1 & POL2 & P3 \\
\hline POL1 & 0 & 1 & 1 \\
POL2 & 1 & 0 & 0 \\
POL3 & 1 & 0 & 0 \\
\hline
\end{tabular}

The third direct influence matrix conceived is about common sustainable manufacturing practices gathered from the literature, named "SMP," as shown in table 5.

Table 5. SMP direct influence matrix (Sustainable Manufacturing Practices DSM)

\begin{tabular}{llllllllll}
\hline & SMP1 & SMP2 & SMP3 & SMP4 & SMP5 & SMP6 & SMP7 & SMP8 & SMP9 \\
\hline SMP1 & 1 & 1 & 0 & 1 & 1 & 1 & 0 & 0 & 1 \\
SMP2 & 1 & 1 & 0 & 0 & 1 & 1 & 1 & 1 & 1 \\
SMP3 & 0 & 0 & 1 & 0 & 1 & 0 & 0 & 0 & 1 \\
SMP4 & 1 & 0 & 0 & 1 & 1 & 1 & 1 & 1 & 1 \\
SMP5 & 1 & 1 & 1 & 1 & 1 & 0 & 1 & 1 & 1 \\
SMP6 & 1 & 1 & 0 & 1 & 1 & 1 & 1 & 1 & 1 \\
SMP7 & 0 & 1 & 0 & 1 & 1 & 1 & 1 & 1 & 1 \\
SMP8 & 0 & 1 & 0 & 1 & 1 & 1 & 1 & 1 & 1 \\
SMP9 & 1 & 1 & 1 & 1 & 1 & 1 & 1 & 1 & 1 \\
\hline
\end{tabular}

The basic idea of our method is to simulate the process that a random walker wanders in the policies network. The random walk algorithm is a stochastic process that describes a walker's path, which contains a succession of random steps on the network's different layers, and the probability that the walker will stay at each node in the network is determined by the nodes' similarity. In the random walk process, the Policies DSM is expressed as the dependency between two policies with the probability $v$ of the random walker on the network. The probabilities that the random walker will move from policy I to $\mathrm{J}$ (or $\mathrm{i}$ to $\mathrm{j}$ ) in the walk matrix $\mathrm{W}$ can be expressed as follows:

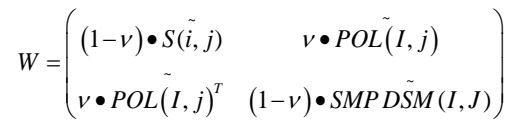

where $S(\tilde{i}, j), P O \tilde{L}(I, j)$, and $\operatorname{SMPD} \tilde{\operatorname{SM}}(I, J)$ are rows normalized to sustainable strategy DSM, Policies DSM, and sustainable manufacturing DSM, respectively. The same methodology was applied in (Kherbachi, Yang, \& Khan, 2020). 


\section{Case study}

The consistency of the proposed model is verified in this section by applying it to the Algerian industry sector. Recently, the Algerian state sheds light on three principal policies: trade, industrial, and innovation policies. The choice of these specific guidelines is justified by the current National Action Plan of Algeria on Sustainable Consumption and Production Modes by 2030. It is part of Algeria's efforts to contribute to Sustainable Development, particularly through the inclusion of this dimension of sustainable development in all public and companies' policies and initiatives by civil society and citizens. Once the practices were selected, we approached the Algerian industrial sector to evaluate the influence of different policies on sustainable manufacturing practices implementation. The influence matrix is designed in Table 6.

Table 6. Policies-SMP influence matrix (POL-SMP DMM)

\begin{tabular}{lccc}
\hline & POL1 & POL2 & POL3 \\
\hline SMP1 & 1 & 0 & 1 \\
SMP2 & 1 & 0 & 1 \\
SMP3 & 1 & 1 & 0 \\
SMP4 & 1 & 0 & 1 \\
SMP5 & 1 & 1 & 1 \\
SMP6 & 1 & 0 & 1 \\
SMP7 & 1 & 0 & 0 \\
SMP8 & 1 & 1 & 1 \\
SMP9 & 1 & 0 & 0 \\
\hline
\end{tabular}

Then, we have conceived the influence matrix containing the different policies encouraging sustainable strategies, as revealed in Table 7.

Table 7. Policies- sustainable strategies influence matrix (POL-S DMM)

\begin{tabular}{lccc}
\hline & POL1 & POL2 & POL3 \\
\hline S1 & 1 & 0 & 1 \\
S2 & 1 & 0 & 1 \\
S3 & 1 & 1 & 0 \\
S4 & 1 & 1 & 1 \\
S5 & 0 & 1 & 1 \\
S6 & 1 & 0 & 1 \\
S7 & 1 & 1 & 1 \\
S8 & 1 & 0 & 0 \\
S9 & 1 & 0 & \\
\hline
\end{tabular}

POL-SMP DMM and POL-S DMM (see Tables 6, 7 \& 8) reveal that innovation policies (1.6, as given in figure 2) encourage sustainable strategies and SMP implementation more than the support given by trade and industrial policies.

Table 8. Policies DSM

\begin{tabular}{lccc}
\hline & POL1 & POL2 & POL3 \\
\hline POL1 & 1 & 0,39 & 0,38 \\
POL2 & 0,37 & 1 & 0,40 \\
POL3 & 0,31 & 0,38 & 1 \\
\hline
\end{tabular}

The support handed by innovation policies comes down to the significant role that innovation plays in the Algerian industrial sector since innovation holds a central place in the sustainable development agenda. Innovation delivers benefits for both manufacturers and stakeholders. It is vital to create better jobs, build a greener society, improve life quality 
Supporting Sustainable Manufacturing Practices Implementation using Design Structure Matrix in the Algerian Economy

and maintain the Algerian industrial sector competitiveness in the global market. Innovation policy constitutes the main interface between technological development policy and industrial policy; it aims at creating a conducive framework for bringing ideas to the industrial landscape.

Figure 2. The weight of different policies

\begin{tabular}{|l|l|}
\hline POL1 & 0,78 \\
\hline POL2 & 0,77 \\
\hline POL3 & 0,69 \\
\hline
\end{tabular}

Rank by Row

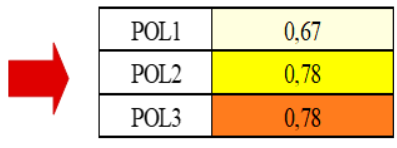

Rank by Column

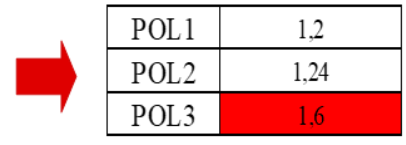

Fin al Rank

The weight of innovation policy is extensively recognized. It is also strongly linked to other Algerian policies, such as those on trade (0.40) and industry (0.38), as indicated in Table 8. The purpose of innovation is to turn research results into new and better products and services to persist competitive in the global marketplace and improve the quality of life of people in Algeria. Besides, it aspires to reduce operational costs and provide a green image that guarantees firms' reputations regarding the environment in the long term. Hence, it aims to support sustainable development goals for tackling the trade-offs between economic, social, and environmental dimensions. Policy DSM also reveals that the Algerian government strives to confirm that trade policy (1.24, as given in figure 2) helps promote sustainable development through trade agreements and trade and development policy. These trade policies aim to guarantee that economic development goes jointly with social justice, human rights respect, high labor and environmental standards to ensure sustainable manufacturing goals across all three dimensions. Industrial policies aimed at promoting the manufacturing industry and encouraging economic development are directly linked to sustainable development, as demonstrated in figure 2 (1.2). Industrial policies can support the development of energy-efficient technologies that would reduce emissions and increase natural resource use efficiency in manufacturing facilities and other urban and rural life elements, including transportation. Thus, a realignment of industrial policies with sustainable development policies can bring significant benefits to society.

In this study, we have first focused on selecting the common sustainable manufacturing practices, sustainable strategies, and policies from the literature. In addition, we have also selected from the literature different indicators allowing the assessment of sustainable strategies defined beforehand. Then, we have applied the random walk method to pretend that a random walker strolls in the policies network. In the random walk process, the Policies DSM is articulated as the dependency between two assigned policies. The main aspiration of this approach is to identify the most policies encouraging sustainable strategies allowing a successful SMP implementation in the Algerian economy. The most significant result indicates that innovation policies provide robust support to SMP implementation in Algerian firms. 


\section{Conclusion}

Following research orientations, this paper explores sustainable manufacturing practices application in Algerian firms. We have zoom on sustainable strategies enabling this application. Policies promoting sustainable strategies are used to reflect the support given by the Algerian government to manufacturers to implement SMP successfully. Results on Algerian manufacturers reveal that innovation policies play an important role in SMP setting up as they foster strategies inciting sustainability in developing economies looking forward. In addition, trade and industrial policies contribute to the application of SMP throughout different policy options and conceive the best actions to back up development priorities and establishing trade and industrial policies framework to ensure effective implementation of such strategies. Additional needed efforts have to be done considering other unspoken policies to explore further the implementation of SMP in developing economies, such as R\&D policies, monetary policies, technology policies, and so on. As original work, this study fulfills its research goals while providing a fruitful roadmap to more helpful research on sustainable manufacturing practices implementation when supported by different policies.

\section{References}

Abdul-Rashid, S., Sakundarini, N., Raja Ghazill, R., \& Thurasamy, R. (2017). The impact of sustainable manufacturing practices on sustainability performance: Empirical evidence from Malaysia. International Journal of Operations and Production Management, 37(2), 182-204.

Afum, E., Osei-Ahenkan, V., Agyabeng-Mensah, Y., Amponsah Owusu, J., Kusi, L., \& Ankomah, J. (2020). Green manufacturing practices and sustainable performance among Ghanaian manufacturing SMEs: the explanatory link of green supply chain integration. Management of Environmental Quality: An International Journal, 31(6), 1457-1475.

Browning, T. R. (2001). Applying the Design Structure Matrix to System Decomposition and Integration Problems: A Review and New Directions. Ieee Transactions On Engineering Management, 48(3), 292-306.

Chung, K., \& AitSahlia, F. (2003). From Random Walks to Markov Chains. In K. Chung, \& F. AitSahlia, Elementary Probability Theory: With Stochastic Processes and an Introduction to Mathematical Finance. Undergraduate Texts in Mathematics (pp. $254-$ 328). New York: Springer.

Deif, A. (2011). A system model for green manufacturing. Journal of Cleaner Production, 19(14), 1553-1559.

Digalwar, A., Thomas, R., \& Rastogi, A. (2021). Evaluation of Factors for Sustainable Manufacturing of Electric Vehicles in India. Procedia CIRP, 98, 505-510.

Fadzlin, A., Zubir, M., \& Habidin, N. (2012). The development of sustainable manufacturing practices and sustainable performance in Malaysian automotive industry. Journal of Economics and Sustainable Development, 3(7), 130-139.

Fagerberg, J. (2017). Innovation policy: Rationales, lessons and challenges. Journal of Economic Surveys , 31(2), 497-512.

Fiorini, M., \& Hoekman, B. (2018). Services trade policy and sustainable development. World Development, 112, 1-12. 
Supporting Sustainable Manufacturing Practices Implementation using Design Structure Matrix in the Algerian Economy

Ilgin, M., \& Gupta, S. (2010). Environmentally conscious manufacturing and product recovery (ECMPRO): A review of the state of the art. Journal of EnvironmentaL Management, 91(3), 563-591.

Joung, C., Carrell, J., Sarkar, P., \& Feng, S. (2013). Categorization of indicators for sustainable manufacturing. Ecological Indicators, 24, 148-157.

Kac, M. (1947). Random Walk and the Theory of Brownian Motion. The American Mathematical Monthly, 54(7), 369-391.

Kherbachi, S., Yang, Q., \& Khan, S. (2020). A structured approach to measuring and optimizing the organizational architecture in global product development projects. Concurrent Engineering , 28(3), 161-174.

Koenta, W., \& Pytel, Z. (1988). Random walk near the surface. Surface Science 200, 374380.

Leal, J. (2020). AHP-express: A simplified version of the analytical hierarchy process method. MethodsX, 7.

Madan Shankar, K., Kannan, D., \& Udhaya Kumar, P. (2017). Analyzing sustainable manufacturing practices - A case study in Indian context. Journal of Cleaner Production, 164, 1332-1343.

Masuda, N., A. Porter, M., \& Lambiotte, R. (2017). Random walks and diffusion on networks. Physics Reports, 58(1), 716-717.

Melton, T. (2005). The benefits of lean manufacturing: What lean thinking has to offer the process industries. Chemical Engineering Research and Design, 83(6A), 662-673.

Millar, H., \& Russell, S. (2011). The adoption of sustainable manufacturing practices in the Caribbean. Business Strategy and the Environment, 20(8), 512-526.

Nill , J., \& Kemp, N. (2009). Evolutionary approaches for sustainable innovation policies: From niche to paradigm? Research Policy, 38(4), 668-680.

Nordin, N., Ashari, H., \& Rajemi, M. (2014). A Case Study of Sustainable Manufacturing Practices. Journal of Advanced Management Science, 2(1), 12-16.

Pearson, K. (1905). The Problem of the Random Walk. Nature, 72(294).

Pinsky, M. A., \& Karlin, S. (2011). Markov Chains: Introduction. In An Introduction to Stochastic Modeling (Fourth ed., pp. 79-163). Academic Press.

Rodrik, D. (2014). Green industrial policy. Oxford Review of Economic Policy, 30(3), 469491.

Rosen, M., \& Kishawy, H. (2012). Sustainable manufacturing and design: Concepts practices and needs. Sustainability, 4(2), 154-174.

Saaty, T. (1984). The analytic hierarchy process: decision making in complex environments. Dans R. Avenhaus, \& R. Huber, Quantitative Assessment in Arms Control (pp. 285-308). Boston, MA: Springer.

Singh, S., Olugu, E., Musa, S., \& Mahat, A. (2016). Strategy selection for sustainable manufacturing with integrated AHP-VIKOR method under interval valued fuzzy environment. International Journal of Advanced Manufacturing Technology, 84(1-4), 547-563.

Wang, Z., Subramanian, N., Gunasekaran, A., Abdulrahman, M., \& Liu, C. (2015). Composite sustainable manufacturing practice and performance framework: Chinese auto-parts suppliers' perspective. International Journal of Production Economics, 170, 219-233. 